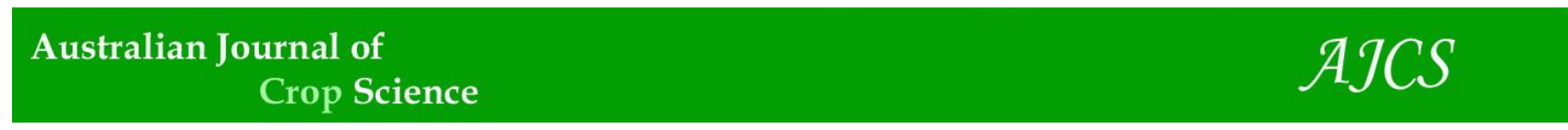

AJCS 12(04):557-562 (2018)

ISSN:1835-2707

doi: 10.21475/ajcs.18.12.04.pne822

\title{
Applying plant oils to control fall armyworm (Spodoptera frugiperda) in corn
}

\author{
Marcelo Sousa Barbosa*, Barbara Barbosa Dias, Mariana Santana Guerra, Gustavo Haralampidou da \\ Costa Vieira
}

\author{
UEMS-UUC, State University of Mato Grosso do Sul, 306 MS Highway km 6.4, Municipality of Cassilândia, MS, Brazil \\ 79540-000
}

*Corresponding author: marcelo_sousad2@hotmail.com

\begin{abstract}
Corn (Zea mays) is one of the world's main agricultural crops, and Spodoptera frugiperda (J. E. Smith) is its most important pest. In order to find natural controlling alternatives, this study aimed to determine the effect of plant oils on the feeding preference of first- and second-instar caterpillars. The experimental design was completely randomized in a $6 \times 5$ factorial combination (turmeric, clove, palmarosa, tea tree, common juniper, and neem oils) at five concentrations $\left(0,25,50,100\right.$, and $\left.200 \mu \mathrm{LL}^{-1}\right)$, plus a control consisting of acetone $\mathbf{1 0 0 . 0 \%}$, with five replicates per treatment. Twenty-five-day-old corn leaf sections received the corresponding treatments in addition to the control and were deposited along orthogonal axes in an arena arranged in Petri dishes. Ten $1^{\text {st }}$ instar caterpillars were released at the center of the plates, and results were obtained after $8 \mathrm{~h}$ and $24 \mathrm{~h}$ from the release, based on the number of caterpillars found on each treatment. For $1^{\text {st }}$ instar caterpillars, the best results were observed for clove and palmarosa, which negatively influenced caterpillar feeding activity in both evaluation periods, followed by turmeric oil, which showed the same effectiveness in the last period only. For second-instar caterpillars, the best effects were observed for neem, turmeric, palmarosa, and clove oil in the first evaluation period. Furthermore, the effectiveness of the first three oils was maintained in the second evaluation period. These results emphasize the potential capability of plant oils when used in management programs against this pest, in which the oils of turmeric, clove and palmarosa showing the best controlling potential of this pest from the lowest concentration corresponding to $25 \mu \mathrm{LL}^{-1}$.
\end{abstract}

Keywords: Spodoptera frugiperda; Aromatic plants; Pests; Caterpillars; Corn.

\section{Introduction}

Corn (Zea mays) has one of the highest economic values as a species. Its kernels can be processed in different ways, such as for fresh consumption. This crop stands out due to its productive potential, as well as its nutritional value. It is one of the cereals most consumed by mankind (Lopes et al., 2016).

Spodoptera frugiperda (J. E. Smith) (Lepidoptera: Noctuidae), commonly known as the fall armyworm, can be highlighted among the various reasons for decreased corn productivity. This pest has great economic interest, due to its extensive defoliation capacity (Arthur et al., 2016).

This insect has polyphagous habits, causing great economic damage, by attacking major crops, such as rice, wheat, cotton, bean, sorghum, etc. Damage varies with crop and planting region (Cruz and Monteiro, 2004).

Corn production in Brazil comes from farms varying from small properties with low technology to large properties with a high technological development levels. In small properties, pest control is not performed at all, or performed inadequately, due to a lack of information and economic conditions. In large properties, pest control focuses on the use of insecticides that lead to resistant population selection problems, ecosystem contamination, and public health problems. In addition, production costs become higher (Viana and Potenza, 2000).

In view of the serious status of this pest, several natural alternative methods have been studied to replace use of agricultural chemicals. The researches have focused on control measures; contributing towards the integrated management of this pest (Labinas and Crocomo, 2002; Haas et al., 2014; Tavares et al., 2013, Tavares et al., 2010).

Among such alternative methods, plant oils occupy an important position. They originate from the secondary metabolism of plants and consist of a mixture of complex chemical substances that act as plant defenses, with low toxicity to animals and to human. They also have antiviral, bactericidal, bacteriostactic, fungicidal, fungistatic, insecticidal, and repellent action (Barbosa et al., 2015; Costa et al., 2011; Morais, 2009; Worwood, 1995). Their metabolic activities are considered to be associated with chemical elements such as aldehydes, alcohols, esters, and phenols, among others (Knaak and Fiuza, 2010).

Souza et al. (2010) studied feeding preference of fourthinstar S. frugiperda caterpillars in assays consisting of corn leaves treated with plant oils from Eucaliptus urograndis (Myrtaceae) and E. urophylla (Myrtaceae). They showed $100 \%$ caterpillar attraction towards the control, confirming 
the inhibitory action of the oils. As mentioned earlier, corn is a cereal with great economic importance. The damage caused by $S$. frugiperda to this crop is extensive. Therefore, this study was carried out to determine the potential of different plant oils on the feeding preference of first- and second-instar S. frugiperda caterpillars.

\section{Results}

Presence of first-instar S. frugiperda caterpillars on corn leaves treated with plant oils after $8 h$ of exposure to the feeding preference test

In the feeding preference test conducted 8 hours from caterpillar release at the lowest concentration $\left(25 \mu \mathrm{LL}^{-1}\right)$, we observed that only the neem and common juniper oils did not differ from the control. All other oils, corresponding to tea tree, turmeric, clove, and palmarosa, influenced caterpillar feeding preference negatively, with lower intakes than the intake obtained for the control (Table 1). At concentrations of 50 and $100 \mathrm{LL} \mathrm{mL}^{-1}$, only the turmeric, clove, and palmarosa oils negatively interfered with caterpillar intake, differing from the control. At these concentrations the number of caterpillars obtained for the neem, tea tree, and common juniper oils did not differ from the control (Table 1). At the concentration of $200 \mathrm{LL} \mathrm{mL}^{-1}$, plant oil effects were observed only for the clove and palmarosa oils. No differences were observed for the other oils compared to the control (Table 1 ).

Presence of first-instar S. frugiperda caterpillars on corn leaves treated with plant oils after $24 h$ of exposure to the feeding preference test

The results obtained in the feeding preference test after 24 hours at the lowest concentration $\left(25 \mu \mathrm{L} \mathrm{mL}^{-1}\right)$ were equal to those observed for the same concentration after exposure for 8 hours. At this concentration the tea tree, turmeric, clove, and palmarosa plant oils were different from the control, suggesting that a non-feeding preference effect occurred on the caterpillars. At this concentration, neem and common juniper did not differ from the control, demonstrating the caterpillar feeding preference for those oils (Table 2). At $50 \mu \mathrm{L} \mathrm{mL}^{-1}$ concentration, the non-feeding preference was maintained for the turmeric, clove, and palmarosa oils. Such effectiveness was maintained at the subsequent concentrations, as well as the low effectiveness for the neem and common juniper oils, which did not differ from the control and from the other concentrations (Table 2). For tea tree oil, the number of caterpillars at the 50 and $200 \mu \mathrm{L} \mathrm{mL}^{-1}$ concentrations did not differ from the control, while at the 25 and $100 \mu \mathrm{L} \mathrm{m}^{-1}$ concentrations the number of caterpillars differed from the control.

Presece of second-instar S. frugiperda caterpillars on corn leaves treated with plant oils after 8 and $24 h$ of exposure to the feeding preference test

Results for second-instar caterpillars are shown in Tables 3 and 4 . In the evaluation performed after $8 \mathrm{~h}$ from caterpillar release, non-feeding preference was observed for the neem, turmeric, clove, and palmarosa oils, while the tea tree and common juniper oils did not differ from the control in all concentrations, denoting feeding preference for these oils (Table 3).

The results of evaluation performed $24 \mathrm{~h}$ after caterpillar release were very close to those observed in the test performed after $8 \mathrm{~h}$, in which the neem, turmeric, and palmarosa plant oils inhibited caterpillar feeding and had a non-preference effect for those oils at all concentrations, differing from the control. Tea tree and common juniper did not show differences compared to the control, supporting the feeding preference of the caterpillars for these oils. In this evaluation period and the $8 \mathrm{~h}$ test different results were observed for clove oil at the two smaller concentrations ( 25 and $50 \mu \mathrm{L} \mathrm{m}{ }^{-1}$ ), showing feeding preference, while at the subsequent concentrations, corresponding to 100 and 200 $\mu \mathrm{L} \mathrm{mL} L^{-1}$, the caterpillars showed non-feeding preference, suggesting a dose-dependent effect (Table 4).

For the $1^{\text {st }}$ instar caterpillars, the best results were observed for clove and palmarosa, which negatively influenced caterpillar feeding activity in both evaluation periods, followed by turmeric oil, which showed the same effectiveness in the last period only. For the second-instar caterpillars, the best effects in the first evaluation period were observed for neem, turmeric, palmarosa, and clove oil. The effectiveness of the first three oils was maintained in the second evaluation period as well. These results emphasized the potential of plant oils when used in management programs against this pest.

\section{Discussion}

Among the oils utilized in this study, neem, family Meliaceae, is one of the most frequently cited in the literature, because of its insecticidal action. Among the studies that demonstrate the insecticidal action of this oil, the investigation conducted by Tavares et al. (2010) reported such effect on S. frugiperda caterpillars. In the feeding preference test conducted in our study with firstinstar caterpillars, the $A$. indica plant oil proved ineffective and did not show inhibitory action when compared with the control. On the other hand, in the results obtained from second-instar caterpillars with evident action, confirmed a non-feeding preference of the pest for the oil.

In this study, the results obtained for first-instar caterpillars contrast with those obtained by Giongo et al. (2016), where they observed an inhibitory action of the same substance after caterpillars were exposed for $24 \mathrm{~h}$ to treated corn leaves.

The insecticidal properties observed for $A$. indica oil are attributed to the presence of azadirachtin, which is a major terpenoid found in this substance (Oliveira, 2015).

The results obtained for tea tree (Myrtaceae) oil on the first- and second-instar caterpillars were similar to those observed by Mazzonetto et al. (2013). These authors determined the feeding preference of $S$. frugiperda caterpillars to corn leaves treated with Corymbia citriodora (Myrtaceae) extract and observed that this family does not negatively interfere with the feeding activity of those insects, compared with the control.

Caterpillar attractiveness to the oil may be related to the chemical components present in that substance, which does not inhibit feeding and does not interfere with choosing 
Table 1. Mean number $( \pm \mathrm{SE})$ of first-instar $S$. frugiperda caterpillars present on corn leaves treated with plant oils after $8 \mathrm{~h}$ of

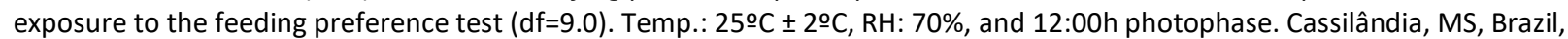
2016.

\begin{tabular}{|c|c|c|c|c|c|c|}
\hline & Neem & Tea Tree & Common Juniper & Turmeric & Clove & Palmarosa \\
\hline \multicolumn{7}{|c|}{ Concentration $\left(25 \mu \mathrm{L} \mathrm{mL}^{-1}\right)$} \\
\hline Control & $2.11 \pm 1.20 \mathrm{a}$ & $1.72 \pm 0.80 \mathrm{~b}$ & $1.65 \pm 0.37 a$ & $2.47 \pm 0.58 b$ & $2.30 \pm 1.28 \mathrm{~b}$ & $1.92 \pm 0.58 b$ \\
\hline Treatment & $1.96 \pm 1.06 a$ & $1.08 \pm 0.20 a$ & $1.65 \pm 1.28 \mathrm{a}$ & $1.08 \pm 0.20 \mathrm{a}$ & $1.37 \pm 0.44 a$ & $1.08 \pm 0.20 \mathrm{a}$ \\
\hline $\mathrm{F}$ (treatment) & $0.071 \mathrm{~ns}$ & $9.579^{*}$ & Ns & $90.548^{* *}$ & $8.221 *$ & $20.674^{*}$ \\
\hline $\mathrm{CV}(\%)$ & 42.44 & 23.33 & 26.06 & 13.03 & 27.91 & 19.54 \\
\hline \multicolumn{7}{|c|}{ Concentration $\left(50 \mu \mathrm{L} \mathrm{mL}^{-1}\right)$} \\
\hline Control & $2.12 \pm 1.15 a$ & $1.61 \pm 0.73 a$ & $1.61 \pm 0.73 a$ & $2.70 \pm 0.67 \mathrm{~b}$ & $2.53 \pm 0.92 b$ & $1.87 \pm 0.50 \mathrm{~b}$ \\
\hline Treatment & $1.94 \pm 0.37 a$ & $1.22 \pm 0.40 \mathrm{a}$ & $1.45 \pm 0.37 a$ & $1.08 \pm 0.20 \mathrm{a}$ & $1.00 \pm 0.00 \mathrm{a}$ & $1.08 \pm 0.20 \mathrm{a}$ \\
\hline $\mathrm{F}$ (treatment) & $0.163 n s$ & $2.091 \mathrm{~ns}$ & $0.236 \mathrm{~ns}$ & $139.646^{* *}$ & $56.083^{* *}$ & $13.773^{*}$ \\
\hline $\mathrm{CV}(\%)$ & 35.25 & 29.52 & 32.69 & 11.47 & 18.34 & 22.85 \\
\hline \multicolumn{7}{|c|}{ Concentration $\left(100 \mu \mathrm{LL}^{-1}\right)$} \\
\hline Control & $2.45 \pm 1.11 a$ & $1.31 \pm 0.37 a$ & $1.57 \pm 1.06 a$ & $2.55 \pm 0.67 \mathrm{~b}$ & $2.11 \pm 0.81 \mathrm{~b}$ & $2.37 \pm 1.06 \mathrm{~b}$ \\
\hline Treatment & $1.95 \pm 0.89 a$ & $1.08 \pm 0.20 a$ & $1.16 \pm 0.24 a$ & $1.08 \pm 0.20 \mathrm{a}$ & $1.00 \pm 0.00 a$ & $1.00 \pm 0.00 \mathrm{a}$ \\
\hline $\mathrm{F}$ (treatment) & $1.374 \mathrm{~ns}$ & $1.344 \mathrm{~ns}$ & $1.430 \mathrm{~ns}$ & $92.381^{* *}$ & $35.319 * *$ & $46.146 * *$ \\
\hline $\mathrm{CV}(\%)$ & 30.60 & 26.21 & 39.72 & 13.30 & 19.01 & 18.96 \\
\hline \multicolumn{7}{|c|}{ Concentration $\left(200 \mu \mathrm{L} \mathrm{mL}^{-1}\right)$} \\
\hline Control & $2.38 \pm 0.73 a$ & $1.22 \pm 0.40 a$ & $1.08 \pm 0.20 \mathrm{a}$ & $2.10 \pm 1.39 a$ & $2.22 \pm 1.06 \mathrm{~b}$ & $2.62 \pm 0.89 b$ \\
\hline Treatment & $2.00 \pm 1.20 \mathrm{a}$ & $1.22 \pm 0.40 a$ & $1.31 \pm 0.37 a$ & $1.22 \pm 0.40 \mathrm{a}$ & $1.00 \pm 0.00 a$ & $1.00 \pm 0.00 a$ \\
\hline $\mathrm{F}$ (treatment) & $0.712 \mathrm{~ns}$ & ns & $2.364 \mathrm{~ns}$ & $4.376 n s$ & $24.020 * *$ & $90.242 * *$ \\
\hline $\mathrm{CV}(\%)$ & 32.68 & 29.78 & 19.69 & 39.83 & 24.51 & 14.92 \\
\hline
\end{tabular}

Means followed by a common letter in the column do not differ from one another by Tukey's test at $5 \%$ probability. SE = standard error of the mean, ns $=$ non-significant, $*(\mathrm{P}<0.05), * *(\mathrm{P}<0.001)$.

Table 2. Mean number $( \pm \mathrm{SE}$ ) of first-instar S. frugiperda caterpillars present on corn leaves treated with plant oils after $24 \mathrm{~h}$ of exposure to the feeding preference test ( $d f=9.0)$. Temp.: 25ㄷ $\pm 2 \circ \mathrm{C}, \mathrm{RH}: 70 \%$, and 12:00hphotophase. Cassilândia, MS, Brazil, 2016.

\begin{tabular}{|c|c|c|c|c|c|c|}
\hline & Neem & Tea Tree & Common Juniper & Turmeric & Clove & Palmarosa \\
\hline Treatment & $1.67 \pm 0.70 \mathrm{a}$ & $1.22 \pm 0.40 \mathrm{a}$ & $2.08 \pm 0.50 \mathrm{a}$ & $1.16 \pm 0.24 a$ & $1.48 \pm 0.67 a$ & $1.08 \pm 0.20 \mathrm{a}$ \\
\hline $\mathrm{CV}(\%)$ & 39.43 & 15.64 & 14.64 & 20.92 & 24.47 & 18.30 \\
\hline \multicolumn{7}{|c|}{ Concentration $\left(50 \mu \mathrm{L} \mathrm{mL}^{-1}\right)$} \\
\hline Control & $2.05 \pm 0.87 a$ & $1.87 \pm 0.96 a$ & $2.27 \pm 0.20 \mathrm{a}$ & $2.99 \pm 0.63 b$ & $2.64 \pm 1.15 b$ & $2.52 \pm 1.20 a$ \\
\hline Treatment & $2.12 \pm 0.76 a$ & $1.55 \pm 0.67 a$ & $1.90 \pm 1.14 a$ & $1.08 \pm 0.20 \mathrm{a}$ & $1.00 \pm 0.00 a$ & $1.48 \pm 0.67 \mathrm{~b}$ \\
\hline $\mathrm{CV}(\%)$ & 25.19 & 10.74 & 24.85 & 12.12 & 18.78 & 29.76 \\
\hline \multicolumn{7}{|c|}{ Concentration $\left(100 \mu \mathrm{LL}^{-1}\right)$} \\
\hline Control & $2.18 \pm 1.00 a$ & $1.44 \pm 0.48 \mathrm{~b}$ & $2.09 \pm 0.87 a$ & $2.67 \pm 0.58 b$ & $2.11 \pm 0.81 b$ & $2.15 \pm 0.86 b$ \\
\hline Treatment & $1.91 \pm 1.46 \mathrm{a}$ & $1.00 \pm 0.00 \mathrm{a}$ & $1.71 \pm 0.44 a$ & $1.31 \pm 0.37 a$ & $1.00 \pm 0.00 a$ & $1.22 \pm 0.40 \mathrm{a}$ \\
\hline $\mathrm{F}$ (treatment) & $0.247 \mathrm{~ns}$ & $7.907^{*}$ & $2.691 \mathrm{~ns}$ & $43.687^{* *}$ & $35.319^{* *}$ & $13.295^{*}$ \\
\hline $\mathrm{CV}(\%)$ & 41.34 & 20.60 & 19.57 & 16.35 & 19.01 & 23.80 \\
\hline
\end{tabular}

Means followed by a common letter in the column do not differ from one another by Tukey's test at $5 \%$ probability. SE = standard error of the mean, ns = non-significant, $*(\mathrm{P}<0.05), * *(\mathrm{P}<0.001)$.

Table 3. Mean number ( $\pm \mathrm{SE}$ ) of second-instar S. frugiperda caterpillars present on corn leaves treated with plant oils after $8 \mathrm{~h}$ of exposure to the feeding preference test ( $\mathrm{df}=9.0)$. Temp.: 25ㅇ $\pm 2{ }^{\circ} \mathrm{C}, \mathrm{RH}: 70 \%$, and 12:00hphotophase. Cassilândia, MS, Brazil, 2016.

\begin{tabular}{|c|c|c|c|c|c|c|}
\hline & Neem & Tea Tree & Common Juniper & Turmeric & Clove & Palmarosa \\
\hline \multicolumn{7}{|c|}{ Concentration $\left(25 \mu \mathrm{L} \mathrm{mL}^{-1}\right)$} \\
\hline Control & $2.56 \pm 1.06 b$ & $1.48 \pm 1.56 a$ & $2.10 \pm 1.31 a$ & $2.70 \pm 0.67 \mathrm{~b}$ & $2.59 \pm 1.22 b$ & $2.66 \pm 0.86 b$ \\
\hline Treatment & $1.08 \pm 0.20 a$ & $1.53 \pm 0.40 \mathrm{a}$ & $2.04 \pm 1.20 \mathrm{a}$ & $1.08 \pm 0.20 \mathrm{a}$ & $1.08 \pm 0.20 \mathrm{a}$ & $1.08 \pm 0.20 \mathrm{a}$ \\
\hline $\mathrm{F}$ (treatment) & $54.155^{* *}$ & $0.012 \mathrm{~ns}$ & $0.010 \mathrm{~ns}$ & $106.265^{* *}$ & $43.377^{* *}$ & $82.107^{* *}$ \\
\hline $\mathrm{CV}(\%)$ & 17.48 & 46.01 & 44.76 & 13.16 & 19.76 & 14.71 \\
\hline \multicolumn{7}{|c|}{ Concentration $\left(50 \mu \mathrm{L} \mathrm{mL}^{-1}\right)$} \\
\hline Control & $7.80 \pm 0.37 b$ & $1.34 \pm 0.63 a$ & $2.29 \pm 0.81 a$ & $2.66 \pm 0.73 b$ & $2.13 \pm 1.01 \mathrm{~b}$ & $2.53 \pm 1.07 \mathrm{~b}$ \\
\hline Treatment & $0.20 \pm 0.20 a$ & $1.28 \pm 0.58 a$ & $1.91 \pm 0.73 a$ & $1.00 \pm 0.0 \mathrm{a}$ & $1.14 \pm 0.40 \mathrm{a}$ & $1.16 \pm 0.24 a$ \\
\hline $\mathrm{F}$ (treatment) & $361.000^{* *}$ & $0.118 \mathrm{~ns}$ & $6.530 \mathrm{~ns}$ & $140.595^{* *}$ & $8.752^{*}$ & 41.844 \\
\hline $\mathrm{CV}(\%)$ & 15.81 & 22.30 & 11.23 & 12.13 & 32.20 & 18.09 \\
\hline \multicolumn{7}{|c|}{ Concentration $\left(100 \mu \mathrm{L} \mathrm{mL}^{-1}\right)$} \\
\hline Control & $2.58 \pm 0.86 b$ & $1.40 \pm 0.73 a$ & $2.18 \pm 1.09 a$ & $2.53 \pm 1.16 b$ & $2.06 \pm 1.28 b$ & $2.75 \pm 1.15 b$ \\
\hline Treatment & $1.20 \pm 0.60 a$ & $1.14 \pm 0.40 \mathrm{a}$ & $1.71 \pm 0.86 a$ & $1.22 \pm 0.40 \mathrm{a}$ & $1.00 \pm 0.00 a$ & $1.00 \pm, 00 \mathrm{a}$ \\
\hline $\mathrm{F}$ (treatment) & $14.950^{*}$ & $0.581 \mathrm{~ns}$ & $1.577 \mathrm{~ns}$ & $17.636^{*}$ & 13.620 & $64.215^{* *}$ \\
\hline $\mathrm{CV}(\%)$ & 29.92 & 41.32 & 30.18 & 26.09 & 29.78 & 18.46 \\
\hline \multicolumn{7}{|c|}{ Concentration $\left(200 \mu \mathrm{L} \mathrm{mL}^{-1}\right)$} \\
\hline Control & $2.40 \pm 1.14 b$ & $1.36 \pm 0.54 a$ & $1.48 \pm 0.58 a$ & $1.93 \pm 0.48 b$ & $2.11 \pm 1.24 \mathrm{~b}$ & $2.74 \pm 1.24 \mathrm{~b}$ \\
\hline Treatment & $1.22 \pm 0.40 a$ & $1.00 \pm 0.00 \mathrm{a}$ & $1.62 \pm 0.67 a$ & $1.08 \pm 0.20 \mathrm{a}$ & $1.00 \pm 0.00 a$ & $1.00 \pm 0.00 \mathrm{a}$ \\
\hline $\mathrm{F}$ (treatment) & $9.450 *$ & $3.965 \mathrm{~ns}$ & $0.444 \mathrm{~ns}$ & $31.639 * *$ & $16.203^{*}$ & $45.520 * *$ \\
\hline $\mathrm{CV}(\%)$ & 33.22 & 24.55 & 22.32 & 15.31 & 28.19 & 21.84 \\
\hline
\end{tabular}

Means followed by a common letter in the column do not differ from one another by Tukey's test at $5 \%$ probability. SE = standard error of the mean, ns $=$ non-significant, $*(\mathrm{P}<0.05), * *(\mathrm{P}<0.001)$. 
Table 4. Mean number ( \pm SE) of second-instar $S$. frugiperda caterpillars present on corn leaves treated with plant oils after $24 \mathrm{~h}$ of exposure to the feeding preference test ( $d f=9.0)$. Temp.: 25ㅇ $\pm 2{ }^{\circ} \mathrm{C}, \mathrm{RH}:$ 70\%, and 12:00hphoto phase. Cassilândia, MS, Brazil, 2016.

\begin{tabular}{|c|c|c|c|c|c|c|}
\hline & Neem & Tea Tree & Common Juniper & Turmeric & Clove & Palmarosa \\
\hline Treatment & $1.54 \pm 0.24 a$ & $1.65 \pm 0.89 a$ & $2.28 \pm 0.92 a$ & $1.08 \pm 0.20 \mathrm{a}$ & $1.08 \pm 0.20 \mathrm{a}$ & $1.44 \pm 0.48 a$ \\
\hline $\mathrm{CV}(\%)$ & 7.73 & 38.58 & 29.32 & 13.16 & 31.80 & 23.19 \\
\hline \multicolumn{7}{|c|}{ Concentration $\left(50 \mu \mathrm{L} \mathrm{mL}^{-1}\right)$} \\
\hline Control & $2.21 \pm 0.63 b$ & $1.42 \pm 0.58 a$ & $2.59 \pm 0.58 a$ & $2.66 \pm 0.73 b$ & $1.86 \pm 0.67 a$ & $2.51 \pm 0.67 b$ \\
\hline $\mathrm{CV}(\%)$ & 17.49 & 17.07 & 19.64 & 12.13 & 28.60 & 9.94 \\
\hline \multicolumn{7}{|c|}{ Concentration $\left(100 \mu \mathrm{L} \mathrm{mL}^{-1}\right)$} \\
\hline Control & $2.55 \pm 0.67 \mathrm{~b}$ & $1.40 \pm 0.73 a$ & $2.25 \pm 0.73 a$ & $2.53 \pm 1.16 b$ & $1.99 \pm 0.31 b$ & $2.15 \pm 0.91 b$ \\
\hline Treatment & $1.08 \pm 0.20 \mathrm{a}$ & $1.14 \pm 0.40 \mathrm{a}$ & $1.84 \pm 0.67 a$ & $1.22 \pm 0.40 \mathrm{a}$ & $1.00 \pm 0.00 \mathrm{a}$ & $1.08 \pm 0.20 a$ \\
\hline $\mathrm{F}$ (treatment) & $56.833^{* *}$ & $0.581 \mathrm{~ns}$ & $1.518 \mathrm{~ns}$ & $17.636^{*}$ & $155.086^{* *}$ & $17.478^{*}$ \\
\hline$C V(\%)$ & 16.97 & 41.32 & 25.54 & 26.09 & 8.43 & 25.01 \\
\hline $\mathrm{CV}(\%)$ & 26.69 & 24.55 & 30.20 & 15.81 & 11.25 & 7.78 \\
\hline
\end{tabular}

Means followed by a common letter in the column do not differ from one another by Tukey's test at $5 \%$ probability. SE $=$ standard error of the mean, $\mathrm{ns}=\mathrm{non}-\mathrm{significant}$, $*(\mathrm{P}<0.05),{ }^{* *}(\mathrm{P}<0.001)$.

between treated and untreated (control) leaves. However, this oil possesses relevant antibacterial and antiinflammatory properties. Castelo et al. (2013) analyzed the chemical composition of $M$. alternifolia oil and verified that the molecules like terpinen-4-ol and 1.8-cineol are the predominant constituents in these substances, responsible for antimicrobial and irritant activities. However, leaf sections treated with clove oil, which is in the same family as the species $M$. alternifolia, showed caterpillar non-feeding preference and demonstrated its inhibitory potential on caterpillar feeding by inducing feeding on untreated leaves only. This observed effect may be associated with the presence of the compound eugenol. Silvestri et al. (2010) studied the chemical composition of E. caryophyllata oil and verified that eugenol is the major compound $(90 \%)$, followed by $\beta$-caryophyllene $(5 \%)$ and eugenol acetate $(2 \%)$. There are other studies in the literature that provide examples of the inhibitory potential of aromatic plants from this family on pest insects, such as in Alves et al. (2014), Corrêa et al. (2011), and Hass et al. (2014). Similar to the results obtained from tea tree, common juniper oil did not interfere with caterpillar feeding preference as well. This substance has the molecules $\alpha$-pinene, $\beta$-pinene, sabinene, camphene, limonene, $\beta$-phellandrene, and neomenthol in its constitution (Porte et al., 2014), whose insecticidal properties have not been cited in the literature. The inhibitory action of turmeric oil (family Zingiberaceae) observed in this study is acknowledged in the scientific community. The literature data indicate that the chemical compounds present in this oil may have acted on the caterpillars by interfering with their feeding and influencing them to seek untreated leaves. According to Tavares et al. (2013) this family has an insecticidal action that operates directly on insect biology. These insecticidal properties are attributed to the presence of phenolic compounds, sesquiterpenes, and ketones. The inhibitory action observed in C. martinii (Poaceae) oil on caterpillar feeding preference is attributed to the chemical compounds geraniol and geranyl acetate, present in the substance at concentrations of 80 and $12 \%$, respectively (Scherer et al. 2009). Other studies that reported the insecticidal potential of plants in the family Poaceae have been conducted by Silva et al. (2016), who determined the effect of Cymbopogon winterianus essential oil at a concentration of $50 \mathrm{mg} \mathrm{mL}^{-1}$ on third-instar S. frugiperdacaterpillars and observed that this substance affects the development and reproductive capacity of these insects. Labinas and Crocomo (2002) offered corn leaves treated with $C$. winterianus plant oil to newly-hatched $S$. frugiperda caterpillars and found that this substance has inhibitory and repellent action. The studies carried out by these authors further support the inhibitory potential of the genus Cymbopogon on the feeding activity of $S$. frugiperda caterpillars.

\section{Materials and Methods}

\section{Experiment site}

The study was conducted at the entomology laboratory of Universidade Estadual do Mato Grosso do Sul (UEMS), in the Cassilândia-MS Unit.

\section{Plant oils used on caterpillars}

The plant oils were purchased from specialty company Herb Workshop - Anvisa number 354340218-477-000401-1-8. Substances intended for commercialization are pure. The oils of Common juniper (Juniperus communis) (Cupressaceae), clove (Eugenia caryophyllata) (Myrtaceae), turmeric (Curcuma longa) (Zingiberaceae), tea tree (Melaleuca alternifolia) (Myrtaceae), palmarosa (Cymbopogon martinii) (Poaceae), and neem (Azadirachta indica) (Meliaceae) were used in the tests. These substances are extracted from the leaves, flowers and stems of these plants at the concentration of $100.0 \%$. The control group was composed only of acetone.

\section{Insect rearing and maintenance}

Caterpillars were collected from a conventional corn crop (variety SHS 4070) grown at the Universidade Estadual de Mato Grosso do Sul campus, in a $400 \mathrm{~m}^{2}$ area. The collected insects were taken to the entomology laboratory and 
maintained in test tubes $(2.5 \mathrm{~cm}$ diameter, $8.5 \mathrm{~cm}$ height) plugged at the top with cotton, containing one individual per tube. The caterpillars were fed disinfested (washed in running water and dipped for 60 seconds in water containing sodium hypochlorite at $2 \%$ ) fresh corn leaves. The leaves were replaced daily.

The caterpillars remained in the rearing vials until the pupal stage was achieved and were then transferred to PVC tube cages ( $30 \mathrm{~cm}$ diameter, $40 \mathrm{~cm}$ height). The top part of those tube cages was closed with voile fabric held in place with wire. Cages were lined with filter paper and placed onto a plastic tray.

The adults were separated into pairs and maintained in the same cages to obtain eggs. Adults were fed with a aqueous honey solution at $10 \%$, imbibed in a cotton wad and maintained in a $50 \mathrm{~mL}$ plastic container. The obtained eggs were transferred to $1000 \mathrm{~mL}$ plastic containers to obtain caterpillars. As the caterpillars reached the first and second instars they were utilized in the tests.

\section{Feeding preference test with $1^{\text {st }}$ and $2^{\text {nd }}$ instar caterpillars}

For this test the plant oils were diluted in acetone at concentrations of $25,50,100$, and $200 \mathrm{~L} \mathrm{~mL}^{-1}$, according to Lima et al. (2009). The experimental design adopted was completely randomized in a $6 \times 5$ factorial combination (plant oils from neem, tea tree, common juniper, turmeric, clove and palmarosa) at five concentrations $(0,25,50,100$, and $200 \mu \mathrm{L} \mathrm{mL}$ ), in addition to a control consisting of acetone only, with five replicates per treatment.

Corn leaves varying from 20 to 25 days of age were cut into leaf sections measuring $2.00 \pm 1.00 \mathrm{~cm}^{2}$. Leaves were dipped for 30 seconds in their respective treatments and deposited at two quadrants along orthogonal axes in a Petri dish $(15.00 \mathrm{~cm}$ diameter and $1.50 \mathrm{~cm}$ height); two other leaf sections comprising the control were placed in the other two quadrants onto filter paper moistened with distilled water. Next, ten first-instar, $24 \mathrm{~h}$-old caterpillars were released at the center of the plates. The number of live caterpillars on the respective treatments was counted $8 \mathrm{~h}$ and $24 \mathrm{~h}$ from the release (Botton et al., 1998). The same procedures adopted in the test with first-instar caterpillars were utilized in the test involving second-instar caterpillars $48 \mathrm{~h}$ of age. The tests were conducted in an air-conditioned room at $25 \pm 2 \circ \mathrm{C}, 70 \pm$ $10 \%$ relative humidity $(\mathrm{RH})$, and $12 \mathrm{~h}$ photoperiod (Torrecillas and Vendramim, 2001).

\section{Statistical analysis}

The variables were transformed to $\sqrt{\mathrm{X}+1}$ and submitted to analysis of variance. The means were compared by Tukey's test at $5 \%$ probability. The statistical analyses were performed with the SISVAR computer program (FERREIRA, 2011).

\section{Conclusion}

Neem plant oil does not interfere with the feeding activity of first-instar S. frugiperda caterpillars; however, this action is observed for second-instar caterpillars. Tea tree and common juniper plant oils do not negatively affect the feeding activity of first- and second-instar S. frugiperda caterpillars. Turmeric, clove, and palmarosa plant oils possess inhibitory action on the feeding activity of first- and second-instar S. frugiperda caterpillars.

\section{Acknowledgments}

We thank Fundação de Apoio ao Desenvolvimento do Ensino, Ciência e Tecnologia do Estado de Mato Grosso do Sul for financial support provided during the conduction of this work.

\section{References}

Alves APC, Correa AD, Alves DS, Saczk AA, Lino JBR, Carvalho GA (2014) Toxicity of the phenolic extract from jabuticabeira (Myrciaria cauliflora (Mart.) O. Berg) fruit skins on Spodoptera frugiperda. Chil J Agr Res. 74: 200204.

Arthur V, Arthur PB, Machi AR (2016) Pupation, adult emergence, and F1 egg hatch after irradiation of Spodoptera frugiperda (Lepidoptera: Noctuidae) last instars. Fla Entomol. 99: 059-061.

Cruz I, Monteiro MAR (2004) Controle biológico da lagarta do cartucho do milho Spodoptera frugiperda utilizando o parasitóide Trichogramma pretiosum. Sete Lagoas: Embrapa Milho e Sorgo (Embrapa Milho e Sorgo. Comunicado técnico, 98) $4 \mathrm{p}$.

Barbosa MS, Vieira GHC, Teixeira AV (2015) Atividade biológica in vitro de própolis e óleos essenciais sobre o fungo Colletotrichum musae isolado de bananeira (Musa spp.). Braz J Med Plan. 17: 254-261.

Botton M, Carbonari JJ, Garcia MS, Martins JFS (1998) Preferência alimentar e biologia de Spodoptera frugiperda (J.E. Smith) (Lepidoptera: Noctuidae) em arroz e capimarroz. An Soc Entomol Bras. 27: 207-212.

Castelo AVM, Afonso SR, Melo RR, Menezzi CHS, Camillo J, Vieira RF (2013) Rendimento e composição química do óleo essencial de Melaleuca alternifolia Chell, na região do Distrito Federal. Rev Bras Cienc Agrar. 8: 143-147.

Corrêa JCR, Salgado HRN (2011) Atividade inseticida das plantas e aplicações: revisão. Braz J Med Plan. 13: 500-506. Costa ART, Amaral MFZJ, Martins PM, Paula JAM, Fiuza TS, Tresvenzol LMF, Paula JR, Bara MTF (2011) Ação do óleo essencial de Syzygium aromaticum (L.) Merr. \& L. M. Perry sobre as hifas de alguns fungos fitopatogênicos. Braz J Med Plan. 13: 240-245.

Ferreira DF (2011) Sisvar: a computer statistical analysis system. Cienc Agrotec. 35: 1039-1042.

Giongo AMM, Vendramim JD, Forim MR (2016) Evaluation of neem-based nanoformulations as alternative to control fall armyworm. Cienc Agrotec. 40: 026-036.

Haas J, Garcia BC, Alves LFA, Haida KS (2014) Efeito de extratos aquosos vegetais sobre a lagarta-do-cartucho. Arq Inst Biol. 81: 079-082.

Knaak N, Fiuza LM (2010) Potencial dos óleos essenciais de plantas no controle de insetos e microrganismos. Neotrop Biol Conser. 5: 120-132.

Labinas AM, Crocomo WB (2002) Effect of java grass (Cymbopogon winterianus Jowitt) essential oil on fall armyworm Spodoptera frugiperda (J. E. Smith, 1797) (Lepidoptera, Noctuidae). Acta Sci-Agron. 24: 1401-1405.

Lima RK, Cardoso MG, Moraes JC, Melo BA, Rodrigues VG, Guimarães PL (2009) Atividade inseticida do óleo essencial de pimenta longa (Piper hispidinervum C. DC.) sobre 
lagarta-do-cartucho do milho Spodoptera frugiperda (J. E. Smith, 1797) (Lepidoptera: Noctuidae). Acta Amazon. 39: 377-382.

Lopes AP, Nóbrega LHP, Pacheco FP, Cruz-Silva CTA (2016) Maize varieties for baby corn yield and post-harvest quality under organic cropping. Biosci J. 32: 298-307.

Mazzonetto F, Coradini F, Corbani RZ, Dalei AB (2013) Ação de inseticidas botânicos sobre a preferência alimentar e sobre posturas de Spodoptera frugiperda (J.E. Smith) (Lepidoptera: Noctuidae) em milho. Entomol Bra. 6: 034038.

Morais LAS (2009) Óleos essenciais no controle fitossanitário. In: Bettiol W, Morandi MAB (ed) Biocontrole de doenças de plantas: uso e perspectivas. Jaguariúna. $1^{\text {nd }}$ edn. Embrapa Meio Ambiente, 139-152.

Oliveira DAB (2015) Uso do neem e seus componentes moleculares no controle do mosquito Aedes aegypti. Rev Cient ITPAC. 8: 02-30.

Porte A, Porte LHM, Oliveira LM (2014) Cromatografia gasosa quiral na resolução de enantiômeros envolvidos em flavours de frutas. Quim Nova. 37: 1670-1679.

Scherer R, Wagner R, Duarte MCT, Godoy HT (2009) Composição e atividades antioxidante e antimicrobiana dos óleos essenciais de cravo-da-índia, citronela e palmarosa. Braz J Med Plan. 11: 442-449.

Silvestri JDF, Paroul N, Czyewski E, Lerin L, Rotava I, Cansian RL, Mossi A, Toniazzo G, Oliveira D, Treichel H (2010) Perfil da composição química e atividades antibacteriana e antioxidante do óleo essencial do cravo-da-índia (Eugenia caryophyllata Thunb.). Rev Cer. 57: 589-594.
Silva CTS, Teixeira VW, Cunha FM, Oliveira JV, Dutra KA, Navarro DMAF, Texeira AAC (2016) Biochemical parameters of Spodoptera frugiperda (J. E. Smith) treated with citronella oil (Cymbopogon winterianus Jowitt ex Bor) and its influence on reproduction. Acta Histochem. 118: 347-352.

Souza TF, Favero S, Conte CO (2010) Bioatividade de óleos essenciais de espécies de eucalipto para o controle de Spodoptera frugiperda (J. E. Smith, 1797) (Lepidoptera: Noctuidae). Rev Bras Agroec. 5: 157-164.

Tavares WS, Freitas SS, Grazziotti GH, Parente LML, Lião LM, Zanuncio JC (2013) Ar-turmerone from Curcuma longa (Zingiberaceae) rhizomes and effects on Sitophilus zeamais (Coleoptera: Curculionidae) and Spodoptera frugiperda (Lepidoptera: Noctuidae). Ind Crop Prod. 46: 158-164.

Tavares WS, Cruz I, Fonseca FG, Gouveia NL, Serrão JE, Zanuncio JC (2010) Deleterious activity of natural products on postures of Spodoptera frugiperda (Lepidoptera: Noctuidae) and Diatraea saccharalis (Lepidoptera: Pyralidae). Z Naturforsch C. 65: 412-418.

Torrecillas SM, Vendramim JD (2001) Extratos aquosos de ramos de Trichilia pallidae o desenvolvimento de Spodoptera frugiperda em genótipos de milho. Sci Agr. 58: 027-031.

Viana PA, Potenza MR (2000) Avaliação de antibiose e nãopreferência em cultivares de milho selecionados com resistência à lagarta-do-cartucho. Bragantia. 59: 027-033.

Worwood S (1995) Aromaterapia Um Guia de A a Z para o uso terapêutico dos óleos essenciais. São Paulo. Editora Best Seller, 251p. 